\title{
Purification and Characterization of a Thrombolytic Enzyme Produced by a New Strain of Bacillus subtilis
}

\author{
Jorge Frias $^{1 *}$, Duarte Toubarro ${ }^{1}$, Alexandra Fraga ${ }^{5}$, Claudia Botelho ${ }^{2,3,4}$, José Teixeira ${ }^{2}$, \\ Jorge Pedrosa ${ }^{5}$, and Nelson Simões ${ }^{1}$ \\ ${ }^{1}$ CBA - Biotechnology Centre of Azores, Faculty of Sciences and Technology, University of Azores, 9500-321 Ponta \\ Delgada, Açores. Portugal \\ ${ }^{2}$ CEB - Centre of Biological Engineering, University of Minho, 4710-057 Braga, Portugal \\ ${ }^{3} C B M A$ - Centre of Molecular and Environmental Biology, University of Minho, 4710-057 Braga, Portugal \\ ${ }^{4}$ INL - International Iberian Nanotechnology Laboratory, 4715-330 Braga, Portugal \\ ${ }^{5}$ ICVS - Life and Health Research Institute, University of Minho, 4710-057 Braga, Portugal
}

\begin{abstract}
Fibrinolytic enzymes with a direct mechanism of action and safer properties are currently requested for thrombolytic therapy. This paper reports on a new enzyme capable of degrading blood clots directly without impairing blood coagulation. This enzyme is also non-cytotoxic and constitutes an alternative to other thrombolytic enzymes known to cause undesired side effects. Twenty-four Bacillus isolates were screened for production of fibrinolytic enzymes using a fibrin agar plate. Based on produced activity, isolate S127e was selected and identified as B. subtilis using the 16S rDNA gene sequence. This strain is of biotechnological interest for producing high fibrinolytic yield and consequently has potential in the industrial field. The purified fibrinolytic enzyme has a molecular mass of $27.3 \mathrm{kDa}$, a predicted $\mathrm{pl}$ of 6.6, and a maximal affinity for Ala-Ala-Pro-Phe. This enzyme was almost completely inhibited by chymostatin with optimal activity at $48^{\circ} \mathrm{C}$ and pH 7. Specific subtilisin features were found in the gene sequence, indicating that this enzyme belongs to the BPN group of the S8 subtilisin family and was assigned as AprE127. This subtilisin increased thromboplastin time by $3.7 \%$ ( 37.6 to $39 \mathrm{~s}$ ) and prothrombin time by $3.2 \%$ (12.6 to $13 \mathrm{~s}$ ), both within normal ranges. In a whole blood euglobulin assay, this enzyme did not impair coagulation but reduced lysis time significantly. Moreover, in an in vitro assay, AprE127 completely dissolved a thrombus of about $1 \mathrm{cc}$ within $\mathbf{5 0}$ min and, in vivo, reduced a thrombus prompted in a rat tail by $11.4 \%$ in $24 \mathrm{~h}$ compared to non-treated animals.
\end{abstract}

Keywords: Bacillus subtilis, subtilisin, fibrinolytic, thrombolytic, direct-acting thrombolytic enzyme

Received: August 6, 2020 Accepted: November 2, 2020

First published online: November 4, 2020

*Corresponding author Phone: +351919687431 E-mail: jorge.mv.frias@uac.pt

pISSN 1017-7825 elSSN 1738-8872

Copyright(C) 2021 by The Korean Society for Microbiology and Biotechnology

\section{Introduction}

Thrombolytic enzymes are currently used to treat cardiovascular diseases, the leading cause of death in the world. According to the World Health Organization [1], 17.5 million people died of cardiovascular diseases in 2012 , and by 2030 , around 23.3 million people are estimated to be afflicted by them. Therefore, the development of more effective and safer therapies is necessary. The three major cardiovascular diseases have thrombosis as a common factor [2], which results from the formation of a thrombus, a blood clot formed after an injury and composed mainly of fibrin. Under normal physiologic conditions, fibrin is hydrolysed by plasmin and the thrombus dissolved, but when fibrin is not hydrolysed due to various physiological reasons, the thrombus enters the bloodstream and increases the risk of thrombosis [3,4]. Currently, the most common clinical treatment is the application of plasminogen activators, such as tissue plasminogen activators (t-PAs), urokinase (Uk), streptokinase (Sk) and nattokinase (Nk) [5-8]. These agents bind plasminogen to convert zymogen into plasmin (the active form in fibrin of the thrombus) and destroy undesired clots. However, bleeding complications caused by systemic activation of fibrinolytic mechanisms present a considerable risk associated with these enzymes $[9,10]$. Therefore, many efforts have been made to develop more effective fibrinolytic agents that lack the known drawbacks of currently used plasminogen activators.

Microorganisms are a great source of fibrinolytic enzymes, and the enzymes used in most thrombolytic therapy (i.e., Sk and Nk) have a bacterial origin. Streptokinase is a single-chain protein with $47 \mathrm{kDa}$, a pI of 4.7 and maximum activity between $\mathrm{pH} 7.3$ and 7.6. It is produced by different strains of $\beta$-hemolytic Streptococci. Nattokinase is a single-chain protein with $20 \mathrm{kDa}$, a pI of 8.6 and is released by Bacillus subtilis natto [7, 11]. Thus, the search for new fibrinolytic enzymes is mostly concerned with microorganisms, which are relatively inexpensive, easy to implement with low cost and characterized by long lifetimes [12, 13]. 
In recent years, bacterial screenings resulted in the isolation and identification of a large number of productive fibrinolytic enzymes, such as Bacillus thuringiensis [14-16], B. subtilis [17], Bacillus sp. [18] and Virgibacillus sp. [19]. Special attention has also been given to microorganisms isolated from different fermented foods [20-22]. Despite fibrinolytic activity differences, none, to date, have identified amino-acid sequences or structural organizations able to explain the strong and weak fibrinolytic activities of different molecules [23-25]. Of the several studies on fibrinolytic enzymes, few have conducted in vitro and in vivo thrombolytic assays using a rat model [26-28]. Fibrinolytic enzymes should be first assessed in animal models to prove their in vivo activity and then evaluated for their potential in human clinical treatment. Thrombolytic agents currently approved by the FDA for patient use are plasminogen activators. Consequently, they do not have a direct-action mechanism over substrate fibrin. Fibrinolytic enzymes with direct-action mechanisms and safer properties are currently requested for thrombolytic therapy [29].

This work describes a new enzyme capable of degrading blood clots without impairing blood coagulation. This enzyme showed a direct-action mechanism by degrading the fibrin substrate without the need to activate other factors. It is also non-cytotoxic and constitutes an alternative to other thrombolytic enzymes (e.g., Nk and Sk) known to cause hemorrhagic complications and other undesired side effects.

\section{Materials and Methods}

\section{Screening for Fibrinolytic Activity}

Twenty-four Bacillus sp. isolated from São Miguel Island in the Azores archipelago and belonging to our bacterial collection with caseinolytic activity, were tested for fibrinolytic activity. Isolates were plated in nutrient agar at $28^{\circ} \mathrm{C}$ for $24 \mathrm{~h}$, and then half a colony of each isolate was transferred to plasminogen-rich and plasminogenfree fibrin agar plates to assess fibrinolytic activity. Plates were prepared by mixing $3 \mathrm{ml}$ of fibrinogen solution ( $1.5 \%$ bovine fibrinogen (Sigma F4129, Portugal) in $20 \mathrm{mM}$ Tris-HCl, pH 7.4), $100 \mu$ l of thrombin solution (Sigma T6884-100 U/ml) and $3 \mathrm{ml}$ of $1 \%$ agarose in $5.5 \mathrm{~cm}$ Petri dishes and allowed to stand for $1 \mathrm{~h}$ at room temperature.

\section{Brute Extract and Enzyme Purification}

The isolate S127e was grown in $250 \mathrm{ml}$ of $\mathrm{LB}$ in a $1 \mathrm{~L}$ flask at $28^{\circ} \mathrm{C}$, at $200 \mathrm{rpm}$ for $18 \mathrm{~h}$. The bacteria were separated by centrifugation at $10,000 \mathrm{~g}$ for $10 \mathrm{~min}$, and the supernatant was filtered in a $0.22 \mu \mathrm{m}$ cellulose acetate membrane (Millipore) and desalted by dialysis against Tris- $\mathrm{HCl}, 50 \mathrm{mM}$, and $\mathrm{pH} 8$. Afterwards, the dialysate was concentrated by tangential flow filtration (TFF) using a polyethersulfone cassette with a cut-off of $10 \mathrm{kDa}$ (Millipore) and stored at $-80^{\circ} \mathrm{C}$ until used. For purification, $1 \mathrm{ml}$ of $100 \times$ concentrated extract was applied in an anionic exchange column HiTrap-HQ (Amersham) coupled to an FPLC system (Amersham, Biosciences), equilibrated with $50 \mathrm{mM}$ Tris- $\mathrm{HCl}, \mathrm{pH} 8$, and the protein was eluted in four steps of $\mathrm{NaCl}(0.1-, 0.2-, 0.5-$, and $1 \mathrm{M})$. Active fractions were pooled, concentrated, and applied in a Superdex-75 column (Amersham), and protein eluted in phosphate buffer (PB), $50 \mathrm{mM}, \mathrm{pH}$ 6. Positive fractions were pooled and applied in a HiTrap-HS (Amersham), equilibrated with the same buffer, and eluted in a linear gradient of 0 to $1 \mathrm{M} \mathrm{NaCl}$. Active fractions were pooled, desalted, concentrated and finally applied in a Mono S column, equilibrated in the same conditions as HiTrap-HS and eluted in a linear gradient of 0 to $1 \mathrm{M} \mathrm{NaCl}$. Fractions were tested for fibrinolytic activity in fibrin agar plates and protein concentration determined using a NanoDrop (Thermo Scientific). The fraction with purified enzyme was desalted, concentrated and stored at $-80^{\circ} \mathrm{C}$ until used.

\section{SDS-PAGE, Zymogram and MS/MS Analysis}

Fractions eluted in the different chromatographies were suspended in non-reducing Laemmli buffer and analyzed in $12 \%$ SDS-PAGE using a Mini-Protean II Gel System (Bio-Rad). Proteins were stained with colloidal Coomassie. A zymogram was performed in $12 \%$ PAGE co-polymerized with $0.05 \%$ gelatine. After electrophoresis, the gels were washed twice for $30 \mathrm{~min}$ in $2.5 \%$ Triton X-100, followed by $30 \mathrm{~min}$ in deionized water and then incubated in $0.1 \mathrm{M}$ Tris- $\mathrm{HCl}$, pH 7.4, plus $0.1 \mathrm{M} \mathrm{NaCl}$ and $5 \mathrm{mM} \mathrm{CaCl}_{2}$, for $60 \mathrm{~min}$ at $37^{\circ} \mathrm{C}$. Proteolysis was detected after Coomassie blue staining. The single protein band in SDS-PAGE resulting from the purified fraction was excised and prepared for MALDI-MS-MS analysis. Monoisotopic masses of the protein were obtained using a MALDI-TOF-MS model Voyager-DE-STR (Applied Biosystems). External mass calibration was performed using a mixture of peptide standards, PepMix1 (LaserBio Labs). The $\mathrm{m} / \mathrm{z}$ masses were used to search in the NCBI non-redundant protein database (www.ncbi.nlm.nih.gov), using the public internet version of Mascot software (www.matrixscience.com) for identification. Trypsin digestion, a maximum of one missing cleavage, a cysteine carbamidomethylation and the possibility of methionine oxidation were selected as conditions in Mascot analyses.

\section{Optimal pH, Temperature and Ionic Concentration for Enzyme Activity}

Determinations of optimal $\mathrm{pH}$, temperature, and ions in buffers were performed in a microplate assay. Optimal $\mathrm{pH}$ was determined by the reaction of $10 \mu \mathrm{l}$ of the purified fraction $(0,50 \mu \mathrm{g} / \mu \mathrm{l}$ of protein) with $50 \mu \mathrm{l}$ of $2 \%$ azoalbumin (w/v) in $40 \mu$ lof buffers at the desired $\mathrm{pH}(0.5 \mathrm{M}$ acetate buffer for $\mathrm{pH} 4,5$ and $6 ; 0.5 \mathrm{M}$ Tris- $\mathrm{HCl}$ for $\mathrm{pH} 7,8$, and 8.8 ) for $1 \mathrm{~h}$ at $37^{\circ} \mathrm{C}$. The reaction was stopped by the addition of $10 \mu \mathrm{l}$ of trichloroacetic acid (100\% w/v), vortexed, incubated on ice for $10 \mathrm{~min}$ and then centrifuged at $10,000 \mathrm{~g}$ for $5 \mathrm{~min}$. The supernatant was transferred to a 96-well plate, neutralized with $10 \mu \mathrm{l}$ of $0.1 \mathrm{~N} \mathrm{NaOH}$, and the absorbance was measured at $450 \mathrm{~nm}$ in a microplate reader (Bio-Rad). The optimal temperature was determined at $16^{\circ} \mathrm{C}, 28^{\circ} \mathrm{C}, 37^{\circ} \mathrm{C}, 48^{\circ} \mathrm{C}$, and $60^{\circ} \mathrm{C}$, as described above in the buffer at $\mathrm{pH}$ 7. The effect of ions was investigated by adding $\mathrm{CuSO}_{4}, \mathrm{ZnSO}_{4}, \mathrm{HgCl}_{2}, \mathrm{MnSO}_{4}$, $\mathrm{CaCl}_{2}, \mathrm{CoCl}_{2}, \mathrm{MgSO}_{4}$, and $\mathrm{FeSO}_{4}$ to the reaction mixture at a final concentration of $1 \mathrm{mM}$, performing the reaction at optimal $\mathrm{pH}$ and temperature. 


\section{Substrate Specificity and Inhibitors}

Proteolytic activity was measured using specific chromogenic substrates N-Suc-Ala-Ala-Pro-Met-pNA (Sigma M7771), Suc-Ala-Ala-Pro-Phe-pNA (Sigma S7388) and Suc-Gly-Gly-Phe-pNA (Sigma S1899) to analyze for chymotrypsin-like activity; Bz-Phe-Val-Arg-pNA (Sigma B7632) and Bz-Pro-Phe-Arg-pNA (Sigma B2133) for thrombin-like activity; Bz-Gly-Gly-Arg-pNA (Sigma C-7784) for urokinase-like activity; Z-d-Arg-Gly-Arg-pNA (Bachem 4029223.0100) for factor Xa like activity; and D-Ile-Pro-Arg-pNA (Sigma I0898) for plasminogen activator-like activity. For the enzymatic assay, $5 \mu \mathrm{l}$ of $10 \mathrm{mM}$ substrate was added to $45 \mu \mathrm{l}$ of the enzyme, at a final concentration of $100 \mu \mathrm{g} / \mathrm{ml}$ diluted in $50 \mathrm{mM}$ Tris- $\mathrm{HCl}, \mathrm{pH} 7.4$, and incubated at $37^{\circ} \mathrm{C}$ for $15 \mathrm{~min}$. The formation of p-nitroaniline (pNA) was monitored at $405 \mathrm{~nm}$ every minute for $10 \mathrm{~min}$ in a microplate reader (Bio-Rad). One unit of enzymatic activity was defined as the amount of the enzyme that produced 1 nmol of p-nitroaniline per minute. The enzyme inhibition was tested using the Suc-Ala-Ala-Pro-Phe-pNA substrate in Tris- $\mathrm{HCl} 50 \mathrm{mM}, \mathrm{pH}$ 7.0 , at $37^{\circ} \mathrm{C}$, with the following protease inhibitors: phenanthroline, chymostatin, phosphoramidon, cystatin $\mathrm{A}$, TPCK, PMSF, and antithrombin at a concentration of $100 \mu \mathrm{M}$; EDTA at a concentration of $10 \mathrm{mM}$; and leupeptin, E64, benzamidine, and soybean trypsin inhibitor at a concentration of $10 \mu \mathrm{M}$.

\section{Fibrinolytic and Fibrinogenolytic Activity Assay}

Fibrinolytic activity was determined in a plasminogen-free fibrin plate, as described in section 2.1. After polymerization, $3 \mathrm{~mm}$ holes were punctured, filled with $10 \mu \mathrm{l}$ of purified AprE127 or urokinase (Sigma U4010) with final concentrations of $5.30,0.60,0.07$, and $0.01 \mathrm{mg} / \mathrm{ml}$, and incubated at $37^{\circ} \mathrm{C}$ for $2 \mathrm{~h}$. Images of the halos in the plate were taken at different times to measure the diameter of hydrolysis. The thrombolytic activity was calculated using the equation $\frac{R}{\sqrt{ }}$, where $R$ is the radius of the halo, and $t$ is the diffusion time [30]. The plasminogen activation assay was performed by reacting $71 \mu \mathrm{g}$ purified S127e with $2.5 \mu \mathrm{g}$ plasminogen (Sigma P7999) in fibrin plates and comparing with the same amount of urokinase. The fibrinogenolytic activity was assayed according to Salazar et al. (2007) with minor modifications [31]. Briefly, $5 \mu \mathrm{g}$ of purified protein AprE127e was added to $50 \mu \mathrm{g}$ of fibrinogen (Sigma F4129), suspended in $100 \mu$ l of Tris- $\mathrm{HCl} 50 \mathrm{mM}, \mathrm{pH} 7.4$ and incubated at $37^{\circ} \mathrm{C}$. Aliquots of $10 \mu \mathrm{l}$ were taken from the reaction mixture at different time points $(0,5,10,20,40$, and $80 \mathrm{~min})$, added to reducing Laemmli buffer, denatured at $95^{\circ} \mathrm{C}$ for $5 \mathrm{~min}$ and run in $12 \%$ SDS-PAGE.

\section{Effect on Euglobulin Clotting and Lysis}

The effect of purified subtilisin S127e on blood coagulation and euglobulin clot lysis time was tested according to Smith et al. (2003) [32]. Human whole blood was collected at two regional health centers (Vila Franca and Nordeste), from adult volunteers after informed consent. The euglobulin fraction was prepared by adding $400 \mu \mathrm{l}$ of citrated human plasma to $3.6 \mathrm{ml}$ of $0.25 \%$ acetic acid (v/v), incubated on ice for $30 \mathrm{~min}$ and then centrifuged at $2,000 \mathrm{~g}$ for $10 \mathrm{~min}$ at $25^{\circ} \mathrm{C}$. The supernatant was completely discharged, and the pellet was suspended in $400 \mu \mathrm{l}$ of $100 \mathrm{mM}$ sodium borate, $\mathrm{pH} 8.4$, and vortexed for $1 \mathrm{~min}$. The clot was then induced by adding $150 \mu \mathrm{l}$ of euglobulin, $10 \mu \mathrm{l}$ of thrombin and $30 \mu \mathrm{l}$ of $0.1 \mathrm{M}$ Tris- $\mathrm{HCl}, \mathrm{pH} 7.5$, into a 96-well plate pre-warmed at $37^{\circ} \mathrm{C}$. To assess the effect of the fibrinolytic enzyme on the clot lysis time, the buffer was replaced by purified AprE127. In the control (without clot formation), the thrombin was replaced by the buffer. Degradation products were measured at $405 \mathrm{~nm}$ every $5 \mathrm{~min}$, for $720 \mathrm{~min}$, using a microplate reader (Bio-Rad).

\section{Determination of APTT and PT}

The effect of the purified AprE127 was tested on coagulation, on activated partial thromboplastin time (APTT) and prothrombin time (TT) using a coagulation analyzer (Diagnostica Stago). Each commercial reagent was reconstituted according to the manufacturer's instructions. Then, $50 \mu \mathrm{l}$ of human plasma was pre-incubated for $5 \mathrm{~min}$ at $37^{\circ} \mathrm{C}$ with $45.9 \mu \mathrm{g}$ of the purified enzyme in $10 \mu \mathrm{l}$ of $50 \mathrm{mM} \mathrm{PBS}, \mathrm{pH}$ 7. As a control, non-treated human plasma was used. Coagulation time was measured in seconds until the full clot was formed.

\section{Thrombolytic Activity on Whole Blood Clots}

To test the thrombolytic activity of the purified enzyme, whole blood clots were performed using fresh human blood. One piece of the blood clot with about $1 \mathrm{~mm}^{3}$ was placed in a well of a 96-well plate, washed three times with $50 \mathrm{mM}$ PBS, $\mathrm{pH}$, and incubated at $37^{\circ} \mathrm{C}$ for $5 \mathrm{~min}$. To each well was added $80 \mu \mathrm{l}$ of the enzyme, diluted in $50 \mathrm{mM}$ PBS, pH 7, to a final concentration of $2.5 \mathrm{mg} / \mathrm{ml}$. The lytic effect was followed and photographed every $10 \mathrm{~min}$. Eighty microliters of urokinase at $2.5 \mathrm{mg} / \mathrm{ml}$ was used as the positive control, and $50 \mathrm{mM} \mathrm{PBS}$, at $\mathrm{pH}$ 7, served as the negative control.

\section{Hemolytic Activity in Mammalian Red Blood Cells}

Quantitative hemolysis was determined by plating $30 \mu \mathrm{l}(75 \mu \mathrm{g} / \mathrm{ml}$ of purified enzyme) into $5 \%$ sheep blood agar plates (COS, Biomerieux) and incubated at $37^{\circ} \mathrm{C}$. The halo resulting from blood lysis was checked after 4 and $18 \mathrm{~h}$ of incubation. Hemolytic activity was assayed using $5 \mu$ heparinized whole human blood incubated with $95 \mu \mathrm{l}$ ( $75 \mu \mathrm{g} / \mathrm{ml}$ of purified enzyme) in $50 \mathrm{mM}$ PBS, $\mathrm{pH} 7.4$, at $37^{\circ} \mathrm{C}$ for $45 \mathrm{~min}$. Cells were then centrifuged at $2,500 \mathrm{~g}$ for $10 \mathrm{~min}$, and the hemoglobin in the supernatant was determined at $545 \mathrm{~nm}$. Serum was used as a blank and $1 \%$ Triton X-100 in $50 \mathrm{mM}$ Tris-HCl, pH 7.4, plus $150 \mathrm{mM} \mathrm{NaCl}$ as a positive control.

\section{Cytotoxic Assay}

The cytotoxicity of the purified AprE127 was tested in Vero cells (Sigma-Aldrich No. 84113001) using the MTT assay. Then, $100 \mu \mathrm{l}$ of Vero cells suspension, with about $10^{5}$ cells, was applied per well in 96 -well plates and 
incubated at $37^{\circ} \mathrm{C}$ for $24 \mathrm{~h}$ in a $\mathrm{CO}_{2}$ chamber. Afterwards, cells were treated with $2.37,4.75$, and $8.5 \mu \mathrm{g} / \mathrm{ml}$ of purified protein. Sodium azide, at $0.5 \mathrm{mM}$, was used as a positive control. After $18 \mathrm{~h}$ of incubation, $5 \mathrm{mg} / \mathrm{ml}$ of MTT solution was added to each well, and the formazan precipitate was dissolved in $100 \mu$ of dimethyl sulfoxide after an incubation period of $4 \mathrm{~h}$. The absorbance of the supernatant was read at $545 \mathrm{~nm}$. Cell viability (\%) was calculated as the OD in treatment / OD in the control $\times 100$.

\section{In Vivo Assay for Thrombolysis}

Six-week-old female Wistar rats weighing 180-200 g, supplied by Charles River in France, were kept in rooms with controlled temperature and humidity with a $12 \mathrm{~h}$ light/dark cycle. Animals were supplied with tap water and a normal pellet diet for at least three days before the experiments. Only animals with tails longer than $13 \mathrm{~cm}$ were used. The assay was performed according to Kamiya et al. (2010) [26]. The animals were anesthetized with dormitor (Medetomidine $0.5 \mathrm{mg} / \mathrm{Kg}$ ) and Imalgene (Ketamine $75 \mathrm{mg} / \mathrm{Kg}$ ). The anesthesia state was reverted with Atipamezole $(1 \mathrm{mg} / \mathrm{kg})$. Then, $200 \mu \mathrm{g}$ of the purified enzyme in $500 \mu \mathrm{l}$ of $50 \mathrm{mM}$ PBS, at pH 7.5, was hypodermically injected per animal at ten different points along the tail of each rat (five points on each side). One hour later, the rats were intravenously injected in the tail vein with $\mathrm{k}$-carrageenan suspended in the same buffer. The thrombus length was measured 24 and $48 \mathrm{~h}$ after the carrageenan injection. In the control group, animals were injected with only $a$-carrageenan in PBS.

\section{Gene Amplification and Sequencing}

Chromosomal DNA of the isolate S127e was extracted using the Bacteria DNA Extraction Kit (Thermo) and used as the template to amplify $16 \mathrm{~S}$ rDNA and S127e subtilisin genes. To identify the isolate, the amplification of the $16 \mathrm{~S}$ rDNA gene was carried out using the forward primer 8F ( $5^{\prime}$-AGTTGATCCTGGCTCAG- $\left.3^{\prime}\right)$ and reverse primer 1492R ( $5^{\prime}$-ACCTTGTTACGACTT-3'). The PCR amplification was carried out under the following conditions: $95^{\circ} \mathrm{C}$ for $3 \mathrm{~min}$, followed by $35 \mathrm{cycles}$ of $95^{\circ} \mathrm{C}$ for $30 \mathrm{sec}, 46^{\circ} \mathrm{C}$ for $30 \mathrm{sec}, 72^{\circ} \mathrm{C}$ for $1 \mathrm{~min}$ and, finally, $72^{\circ} \mathrm{C}$ for $2 \mathrm{~min}$. The amplicons were purified using the PCR Clean-Up System (Promega) and then sequenced in STAB VIDA (Portugal).

The amplification of the S127e subtilisin encoding gene was performed with the degenerated primers Bk-5'GCGCAATCCGTGCCTTACGGC-3' and reverse Bk-5'-TTATTGTGCAGCCGCCTGTACGTTG-3', designed based on the homologous references that were predicted by mass spectrometry analysis of the purified protein. The following PCR conditions were used: $95^{\circ} \mathrm{C}$ for $4 \mathrm{~min}$, followed by 30 cycles of $95^{\circ} \mathrm{C}$ for $45 \mathrm{sec}, 55^{\circ} \mathrm{C}$ for $45 \mathrm{sec}$, $72^{\circ} \mathrm{C}$ for $1.5 \mathrm{~min}$ and $72^{\circ} \mathrm{C}$ for $5 \mathrm{~min}$. The PCR products were run in agarose gel. The amplified fragments were excised and then sequenced in STAB VIDA (Portugal).

\section{Bioinformatic Analysis}

Protein motifs were identified using SMART (http://smart.embl-heidelberg.de/) and the conserved domain database from NCBI (http://www.ncbi.nlm.nih.gov/Structure/cdd/wrpsb.cgi). Sequence identities were determined by BLAST against the NCBI general database (http://www.ncbi.nlm.nih.gov/BLAST/). Multi-sequence analysis of homologous genes was performed using CLUSTAL W implemented in BioEdit 7.0. The 3D structure was predicted using the I-TASSER server (http://zhanglab.ccmb.med.umich.edu/I-TASSER).

\section{Sequences Submitted to Public Database}

The 16S rDNA sequence of isolate S127e was submitted to NCBI, with accession number MN069579. The gene encoding the mature subtilisin, named AprE127, was submitted to NCBI, with accession number MF281668.

\section{Statistical Analysis}

The statistical analyses were performed in Prism software (GraphPad Software, version 7.0, USA). All experiments were performed in triplicate and repeated three times with similar results. The data from in vivo thrombolytic assay were evaluated using Student's $t$-test. Differences were considered statistically significant for $p$ values $<0.10$. The numbers of biological repetitions are depicted in the figure legends.

\section{Results}

Identification of Fibrinolytic Strain and Enzyme Purification

Six of the 24 isolates of Bacillus sp. demonstrated different rates of fibrinolytic activity. Based on the halo diameter of fibrin lysis, the isolate S127e, which presented the highest activity was selected. This isolate has a $16 \mathrm{~S}$ rDNA (NCBI Acc. No. MN069579) and subtilisin named AprE127 (NCBI Acc. No. MF281668) sequences with $99.65 \%$ and $98.53 \%$ identity with those of B. subtilis P52 and J-5 strains, respectively. Therefore, it was assigned as a new isolate of B. subtilis. Cultures of B. subtilis S127e were deposited at the DSMZ (German Collection of Microorganisms and Cell Cultures) under the reference DSM 106532.

The fibrinolytic enzyme was purified using four sequential chromatographies (Figs. 1A-1D) with a purification factor of 78.2 (Table 1). The purified protein with fibrinolytic activity has an estimated molecular weight of $27 \mathrm{kDa}$ based on SDS-PAGE and zymogram analyses (Fig. 1E). MALDI-MS-MS of the pure excised band originated six peptides (Table 2) covering $29 \%$ of the entire protein and matching a subtilisin-like serine protease of B. subtilis (NCBI Acc. No. AAY23643), with the significant score of 505 (scores greater than 75 are significant at $p<0.05$ ). Using primers designed based on sequences identified by MS, an ORF was amplified with $825 \mathrm{bp}$ that encodes for the purified enzyme. A BLAST search of the NCBI database showed that AprE127 had 0.98 identities with the subtilisins AprE176 (AHN52401) and DJ-4 (Acc. AAT45900), 0.97 with subtilisin K54 (AAC63365), and 0.85 


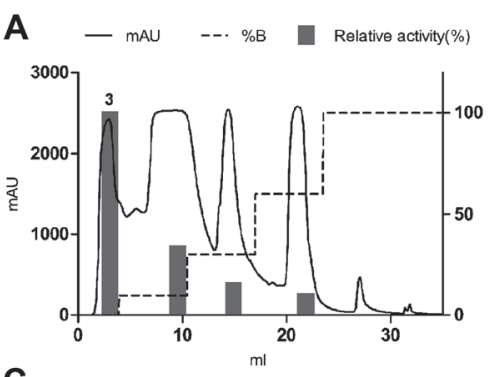

C

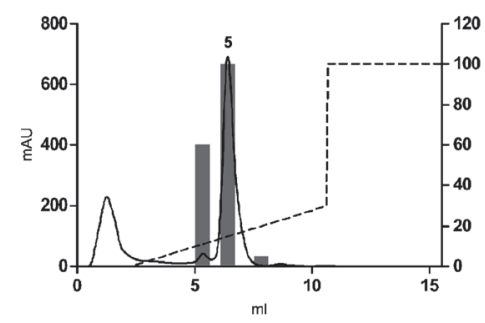

B

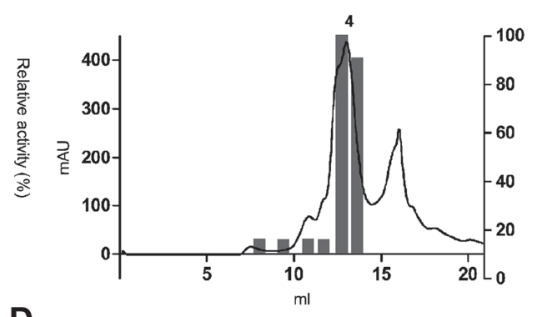

D

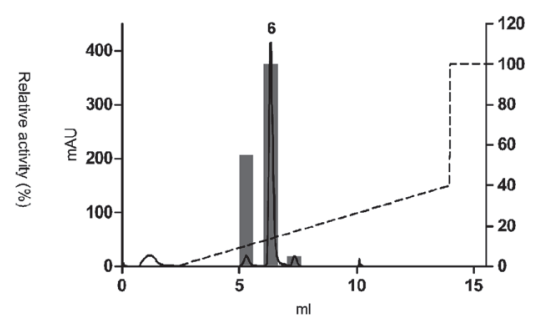

$\mathbf{E}$

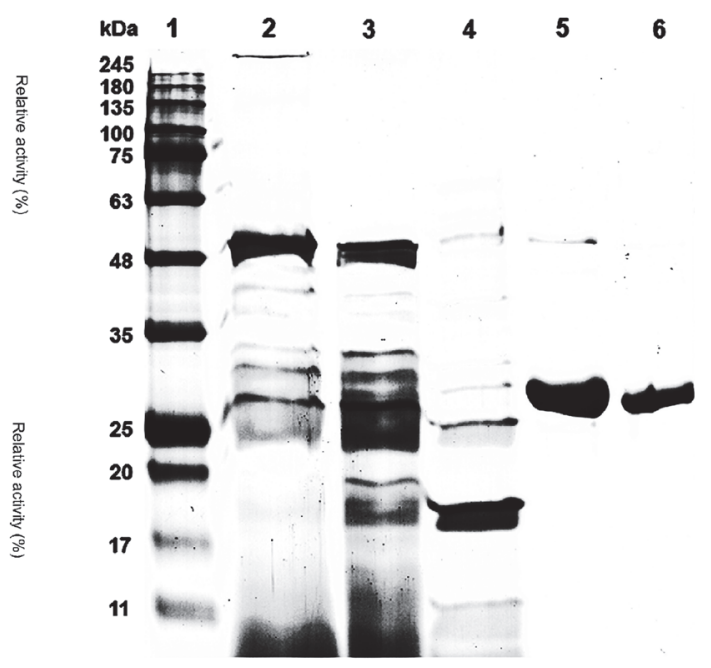

Fig. 1. Purification of AprE127. The enzyme was purified in four consecutive chromatographies: anionic exchange (A), gel filtration (B) and cationic exchange (C and D); SDS-PAGE of proteins in the sequential steps of purification (E) [1 - Molecular markers; 2 - supernatant of bacterial culture; 3 - active fractions from anionic exchange; 4 - active fraction from gel filtration; 5 - active fraction from the 1st cationic exchange; 6 - active fraction from the 2 nd cationic exchange].

with the subtilisins Nk1 (nattokinase, AAX35771) and Nat (nattokinase, AAC60424), all of them produced by B. subtilis. AprE127 encodes for an open reading frame of 272 amino acid residues, with a predicted molecular weight of $27.3 \mathrm{kDa}$, close to the molecular weight calculated by SDS-PAGE, and a predicted pI of 6.6. The molecular weight is close to the nattokinase [24, 34, 36], CK [35], subtilisin DJ-4 [38] and to the Subtilisin DFE [39], which are 27.7, 28.2, 29, and $28 \mathrm{kDa}$. However, it has a lower molecular weight than other proteases from Bacillus spp., like the jeotgal [42] and KDO-13 [43], which have 41 and $45 \mathrm{kDa}$, respectively. Also, at around 8.0, the isoelectric point resembled other fibrinolytic enzymes $[38,44]$ but was different from bpDJ-2, which is pI 3.53.7 [45]. SMART assembly analyses allowed the identification of a subtilisin-like domain between 25 to 253 aa, with the active site residues Asp-32, His-64, Ile-107, Leu-126, Asn-155, and Ser-221. It is known that almost all serine fibrinolytic enzymes belong to subtilisin of Bacillus origin and own the same catalytic triad with Asp-32, His-64, and Ser-221, without intramolecular disulfide bonds [24]. The order of catalytic residues Asp/His/Ser is a well-conserved feature indicating that AprE127 belongs to clan Bs and the S8 subtilisin family of serine proteases. In this triad, His takes part of the proton donor, and Asp is needed for the orientation of the imidazolium ring of His [33]. The 3D analysis of AprE127 is allowed to predict an identical fold to BPN subtilisin (PDB Acc. No. $1 \mathrm{~s} 01 \mathrm{~A}$ ) with a confidence score of 1.76 and an estimated model accuracy of $0.96 \pm 0.05$ (TM-score). This model evidenced the $\alpha / \beta$-fold typical of the S8 subtilisin family, with a twisted central $\beta$-sheet containing seven strands surrounded by nine $\alpha$-helices, with the active site residues converging to form the substrate binding loop (Fig. 2A), similar to other known crystal structures but with non-conserved amino acid residues flanking the catalytic triad (Fig. 2B).

The phylogenetic analyses showed that AprE127 is closer to the bacterial subtypes subtilisin BPN (S08.034) than to the subtilisins Carlsberg (S08.001), TK (S08,129), or PB92 (S08.003) (Fig. 2C).

Table 1. Table of enzyme purification.

\begin{tabular}{lcccc}
\hline \multicolumn{1}{c}{ Steps } & Total protein $(\mathrm{mg})$ & Total act. $(\mathrm{U})$ & Specf. act. (U/mg) & Purif. fold \\
\hline Supernantant & 145.6 & 1655 & 11 & \\
HiTrap HQ & 12.40 & 1604 & 129 & 11.7 \\
HiTrap HS & 1.68 & 1218 & 725 & 65.9 \\
Mono HS & 0.72 & 620 & 861 & 78.2 \\
\hline
\end{tabular}

Table 2. Peptides identified in AprE127 subtilisin by Maldi - MS/MS.

\begin{tabular}{clcccc}
\hline Total score & \multicolumn{1}{c}{ Ms/Ms peptides } & Calc. mass & Obsrv. mass & Error \pm da & Ion score \\
\hline \multirow{2}{*}{505} & SSLENTTTK & 980.5 & 980.5 & -0.0105 & 11 \\
& LGDAFYYGK & 1033.5 & 1033.5 & -0.043 & 53 \\
& HPNWTNTQVR & 1252.6 & 1252.6 & -0.0544 & 71 \\
& AQSVPYGVSQIK & 1276.7 & 1276.6 & -0.0547 & 59 \\
& APALHSQGFTGSNVK & 1513.8 & 1513.7 & -0.0542 & 136 \\
& YPSVIAVGAVNSSNQR & 1661.9 & 1661.9 & -0.0712 & 163 \\
\hline
\end{tabular}



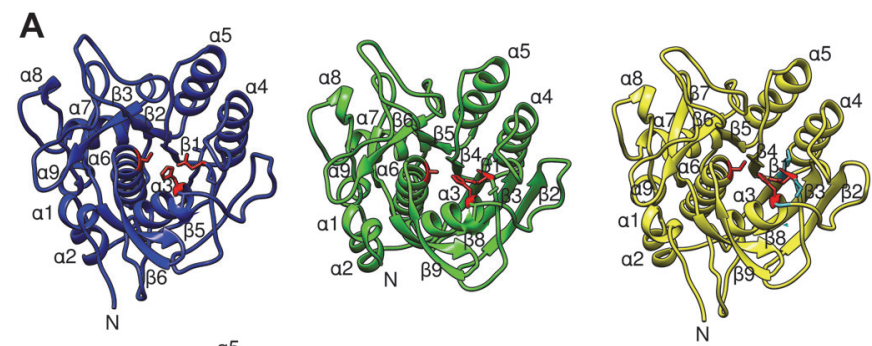

C
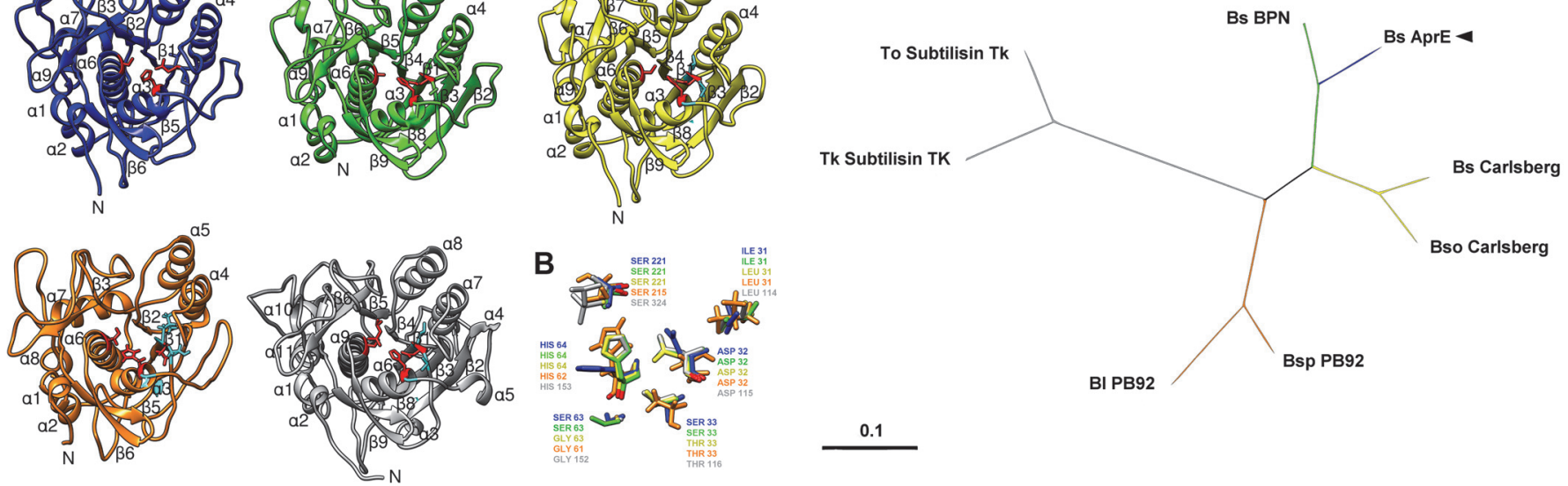

0.1

Fig. 2. Predicted 3D structure of AprE127 and its comparison with close homologues (A): AprE127 in blue, Subtilisin BPN (1s01) in green, Subtilisin Carlsberg (1bfu) in yellow, Subtilisin PB92 (1ah2) in orange, and Subtilisin Tk (2z2x) in gray; Catalytic triad residues (red) and flanking non-conserved residues (cyan). Superimposed catalytic triad residues and flanking non-conserved residues (B): The amino acid residues are labeled and colored according to previously stated structures. The phylogenetic blast of AprE127 with the different groups of subtilisins (C): Bs_Carlsberg (1SBC_A); Bso_Carlsberg (WP_006636716); Bsp_PB92 (CAA01128); Bl_PB92 (AFK08970); Tk_Subtilisin_TK (2Z2Y_C); To_Subtilisin_TK(WP_088885546); Bs_BPN_natto (ACJ06132).

Biochemical Characterization of AprE127

AprE127 showed the highest activity in the specific substrate for subtilisins and chymotrypsins Suc-Ala-AlaPro-Phe-pNa, with $31.5 \pm 1.4 \mathrm{U} / \mathrm{min}$, followed by Suc-Ala-Ala-Pro-Met-pNa, with only $5.2 \pm 0.6 \mathrm{U} / \mathrm{min}$ (Table 3 ). No activity was detected in substrates used to test enzymes involved in coagulation cascade (e.g., thrombin and factor Xa), neither in substrates of plasminogen activators (e.g., urokinase and plasminogen activator), all of them with Arg in the P1 position.

AprE127 activity was strongly inhibited by chymostatin (80\%), a well-known inhibitor of serine chymotrypsin-

Table 3. Comparative amidolytic activity in several synthetic substrates.

\begin{tabular}{lc}
\hline Synthetic substrate $(1 \mathrm{mM})$ & Substrate hydrolysis (U/min) \\
\hline N-Suc-Ala-Ala-Pro-Phe-pNA & $31.5 \pm 1.4$ \\
N-Suc-Ala-Ala-Pro-Met-pNA & $5.2 \pm 0.6$ \\
N-Suc-Gly-Gly-Phe-pNA & 0 \\
N-Bz-Phe-Val-Arg-pNA & 0 \\
N-Bz-Pro-Phe-Arg-pNA & 0 \\
N-Bz-Gly-Gly-Arg-pNA & 0 \\
Z-d-Arg-Gly-Arg-pNA & 0 \\
D-lle-Pro-Arg-pNA & 0 \\
\hline
\end{tabular}

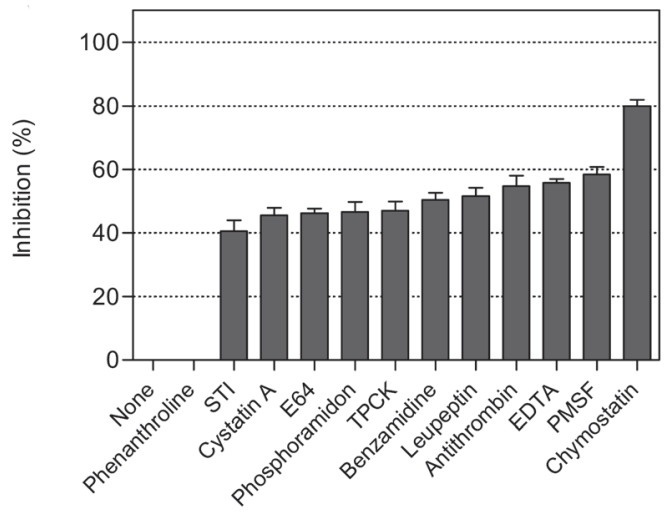

Fig. 3. Biochemical characterization of AprE127 subtilisin. Effect of different inhibitors in the enzyme activity. Data are presented as mean $\pm \mathrm{SD}, n=3$. 
A

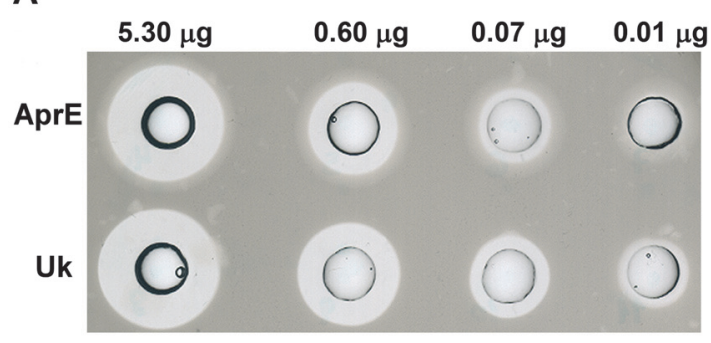

B

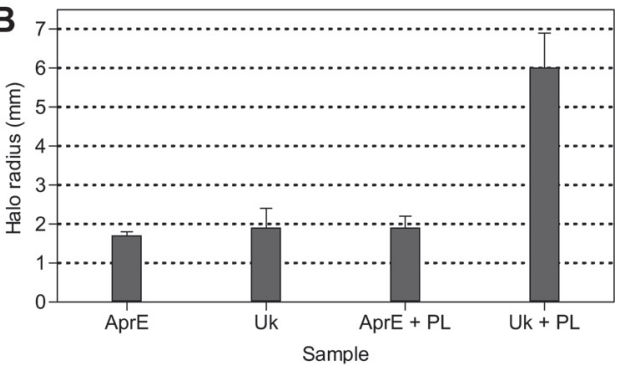

Fig. 4. The activity of AprE127 subtilisin in fibrin and plasminogen activator assay. Comparison of fibrinolytic activities of AprE127 subtilisin (first line of wells) and human urokinase (second line of wells) at the same concentrations (A): 5.30, 0.60, 0.07, and $0.01 \mu \mathrm{g}$. Plasminogen activator assay (B): AprE127 subtilisin (AprE) and human urokinase (Uk) applied separately in the same concentrations, AprE127 subtilisin plus plasminogen (AprE + PL), human urokinase plus plasminogen $(\mathrm{Ul}+\mathrm{PL})$, both in the same concentration ratio. Data are presented as mean $\pm \mathrm{SD}, n=3$.

like enzymes, and partially by PMSF (58 \%), different from almost all other fibrinolytic enzymes (Fig. 3). AprE127 was active at $\mathrm{pH}$ within 6.0 and 8.8 , with an optimum at 7.0 , and in the thermal range $37-60^{\circ} \mathrm{C}$, with an optimum at $48^{\circ} \mathrm{C}$. The optimal temperature and $\mathrm{pH}$ were comparable to the optimal conditions of other relative serine proteases active at neutral and alkaline $\mathrm{pH}$ [37-39]. The catalytic activity of AprE127 increased by $80 \%$ in the presence of $1 \mathrm{mM}$ of $\mathrm{Mg}^{2+}(5.2 \pm 0.6 \mathrm{U} / \mathrm{min}$ to $9.3 \pm 0.5 \mathrm{U} / \mathrm{min})$ and $10 \%$ in the presence of $\mathrm{Ca}^{2+}$, differently from other fibrinolytic enzymes like NAT, DC-4, and AprE176, which are activated by $\mathrm{Ca}^{2+}$ but not by $\mathrm{Mg}^{2+}$. On the other hand, AprE127 was inhibited in the presence of $\mathrm{Cu}^{2+}(80 \%), \mathrm{Zn}^{2+}(80 \%)$, and $\mathrm{Hg}^{2+}(70 \%)$. It is well documented that divalent metal ions act as a cofactor in many BPN fibrinolytic enzymes, playing an important role in the catalytic reactions [13].

\section{Fibrinolytic and Thrombolytic Activity of AprE127}

The fibrinolytic activity of AprE127 and urokinase in a fibrin plate assay were compared, and both enzymes formed similar halos of fibrinolysis (Fig. 4A). Assays showed that both enzymes have identical constant activities, 1.85 and 2 for AprE and urokinase, respectively. Thus, the specific activity calculated for AprE was $3.8 \mathrm{U} / \mu \mathrm{g}$ (urokinase unit equivalents). We also tested whether AprE127 was or was not an activator of plasminogen, by comparing its effect with that of urokinase. The halo formed in a fibrin plate by AprE127 alone did not differ from that formed by plasminogen plus AprE127, whereas a significant increase in the halo was observed with the application of plasminogen and urokinase (Fig. 4B).

Moreover, the hydrolytic activity of AprE127 on fibrinogen was analyzed by an in vitro reaction. The SDSPAGE profile of the digestion products of fibrinogen showed the complete hydrolysis of the $\alpha$ - chain in less than 20 min of incubation, whereas $\beta$ - and $\gamma$-chains were not completely digested after $80 \mathrm{~min}$ of reaction (Fig. 5). This data points to the strong $\alpha$ - and moderate $\beta$ - and $\gamma$-fibrinogenase activity of AprE127.

The effect of AprE127 in coagulation was investigated using activated partial thromboplastin time (APTT),

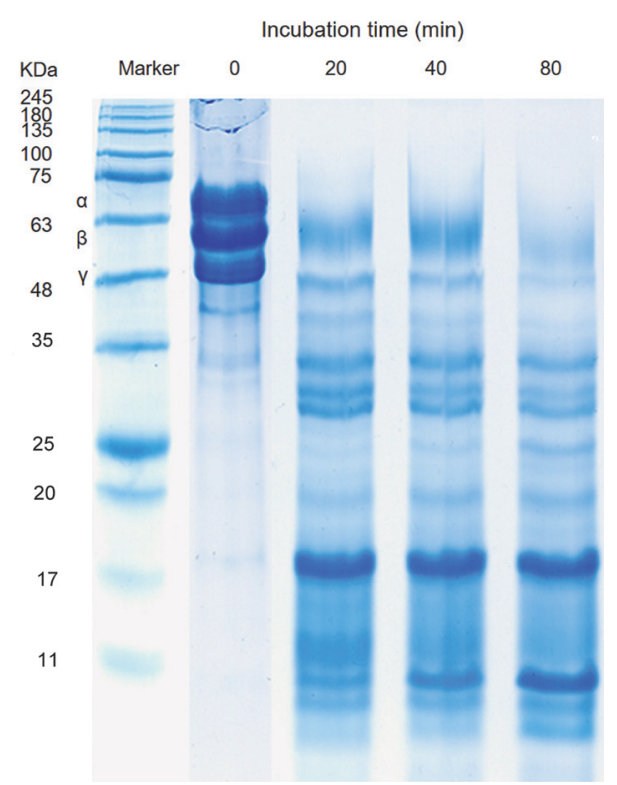

Fig. 5. Digestion pattern of the AprE127 subtilisin in fibrinogen. 
Table 4. Activated partial thromboplastin time (APTT) and prothrombin time (PT) in whole blood sample treated and untreated with AprE127 subtilisin.

\begin{tabular}{lcc}
\hline Assay & Control (s) & Treated (s) \\
\hline APTT & $37.6 \pm 1.2$ & $39 \pm 1.5$ \\
PT & $12.6 \pm 0.4$ & $13 \pm 0.5$ \\
\hline
\end{tabular}

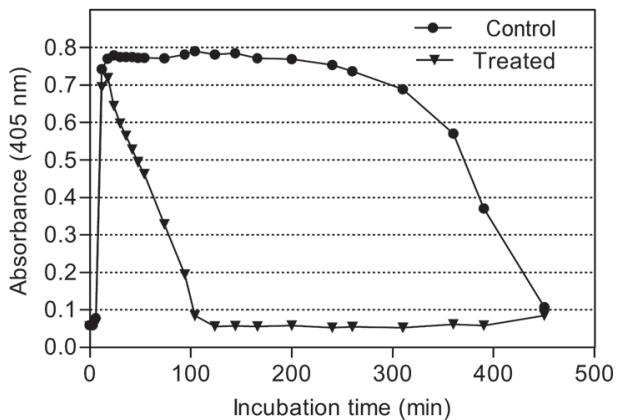

Fig. 6. The activity of AprE127 subtilisin in fibrinolysis. Clot lysis time of euglobulin treated and untreated with AprE127 subtilisin. Data are presented as mean \pm SD, $n=3$.

prothrombin time (PT) and euglobulin clot lysis time. Despite the strong activity of AprE127 in the hydrolysis of a-fibrinogen, a slight increase in APTT (from 37.6 to $39 \mathrm{~s}$ ) and PT (from 12.6 to $13 \mathrm{~s}$ ) was observed (Table 4), both within the normal range values (27-40 s for APTT and 11-14 s for PT). The assay performed with the blood fraction euglobulin that contained fibrinogen, plasminogen and PA allowed the confirmation that AprE127 did not impair the clot formation, which occurred within the same time and almost in the same extension in treated and non-treated euglobulin (Fig. 6). Nevertheless, AprE127 reduced the fibrinolysis time. In the control, the clot lysis curve was $462 \mathrm{~min}$, whereas in euglobulin treated with AprE127, it was reduced to $100 \mathrm{~min}$ and started shortly after coagulation.

A

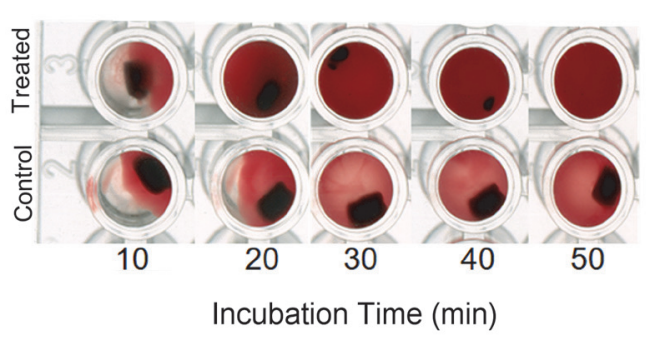

B

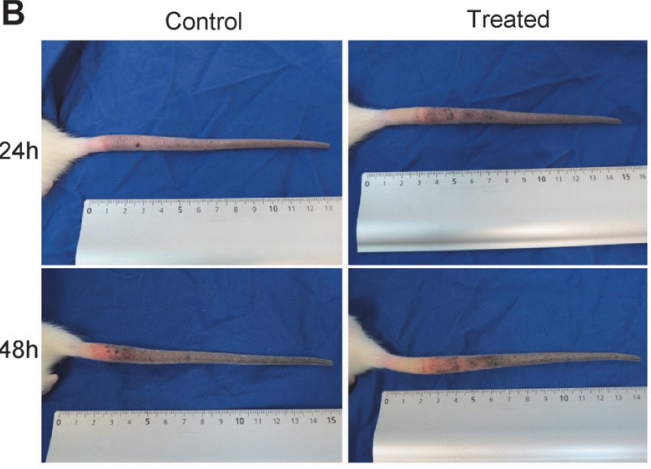

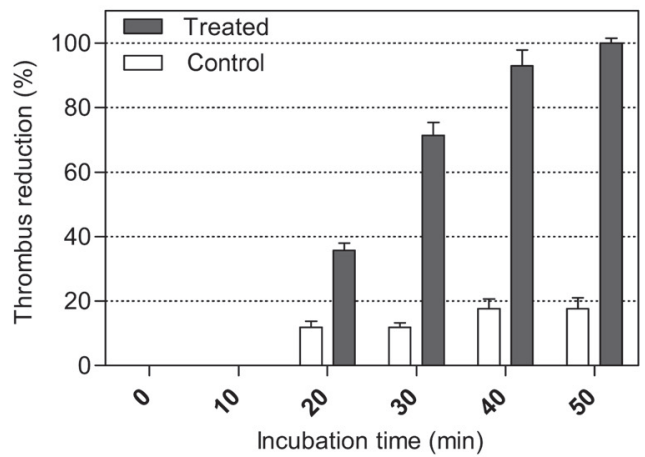

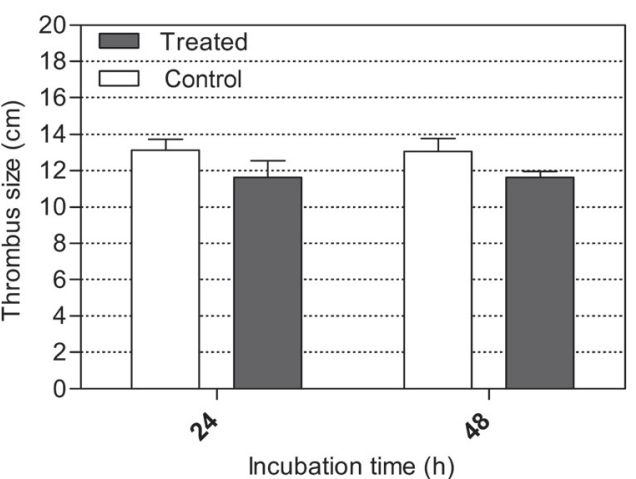

Fig. 7. thrombolytic effects of AprE127 subtilisin. Lytic effect of the enzyme on whole blood clots performed in vitro (A); thrombolytic effect of the enzyme in an in vivo assay, on thrombus, induced by carrageenan in a rat tail (B). In both graphs, columns represent mean $\pm \mathrm{SD}, n=3$. The asterisk shows the significant difference $(p=0.079)$ between the control and treated group (Student's $t$-test). 
The in vitro thrombolytic effect of AprE127 in thrombus with about $1 \mathrm{~mm}^{3}$ was tested. The treatment with $250 \mu \mathrm{g} /$ $\mathrm{ml}$ of AprE127 completely dissolved the thrombus in about $50 \mathrm{~min}$ (Fig. 7A). The activity of AprE127 in degrading thrombi in vivo was assayed in the tails of Wistar rats in which thrombosis was induced by the injection of carrageenan, as previously reported $[26,27]$. The average extension of the thrombi formed on the control animals was $13.13 \pm 0.6 \mathrm{~cm}$, while the extension of the thrombi formed in the animals injected with AprE127 was $11.63 \pm$ $0.9 \mathrm{~cm}$. This represented an $11.4 \%$ reduction in $24 \mathrm{~h}$ post-treatment (Fig. $7 \mathrm{~B}$ ). It should be noted that this effect of AprE127 remained $48 \mathrm{~h}$ post-treatment (Fig. $7 \mathrm{~B}$ ).

\section{Toxicity Assessment of the Enzyme}

The hemolytic activity of AprE127 was tested in blood agar plates and whole blood. This enzyme did not cause any lytic halo in sheep blood cell plates after $18 \mathrm{~h}$ of incubation. In the whole blood hemolytic assay, 90\% of hemocytes were viable after treatment with AprE127, whereas in the control group, only 5\% of cells remained viable.

In Vero cells, the toxicity of AprE127 was under 5\% after $18 \mathrm{~h}$ of incubation at concentrations up to $8.5 \mathrm{mg} / \mathrm{ml}$, while cells treated with sodium azide (control) presented $80 \%$ mortality.

\section{Discussion}

Due to medical interest in fibrinolytic enzymes produced by B. subtilis strains (e.g., Nk), it was decided to screen for other potent thrombolytic enzymes as alternatives to currently approved plasminogen activators, as they lack direct-action mechanisms over substrate fibrin. The AprE127 encoding gene has high homology with the Nkgene of B. subtilis [34], the subtilisin BPN of B. amyloliquefaciens [35] and with the subtilisin E of Bacillus subtilis [13], but diverges from the TK, Carlsberg and Pb92 subtilisin groups. The superimposed structures of AprE127, subtilisin $\mathrm{TK}$, Carlsberg, and $\mathrm{Pb} 92$ groups shows that some residues flanking the active site are not conserved (Figs. 2A-2B). For example, residue 31, which is flanking the active site residue Asp 32, is Ile in AprE127, but Leu in the other groups. Also, residue 33 in AprE127 is Ser, but Thr in the other groups. Another difference is at residue 63 flanking the His residue of the catalytic triad, where the polar amino acid Ser is switched to the less reactive amino acid Gly in the other three groups (Fig. 2B). These important findings are consistent with previous research hypothesizing that the catalytic activity can be influenced by small structural changes in the primary sequence flanking the active site residues. The substitution of amino acids flanking the conserved catalytic triad residues may contribute to forming different structural conformations that translate into different activities. The BPN group includes the largest number of fibrinolytic enzymes with the highest specificity to fibrin substrate of the entire subtilisin family [13]. Despite the great homology of these sequences, only a few of these fibrinolytic enzymes have high substrate specificity to fibrin, which can only be explained by evolutionary changes of the critical amino acid residues in the substrate-binding site [13]. Moreover, all the subtilisins belonging to AprE are fibrinolytic and have high substrate specificity to fibrin, differing from other proteases with fibrinolytic activity but with a broad spectrum $[24,34,36-39]$.

Based on these results, AprE127 had a great affinity to substrates with large aromatic residues in the P1 position, similar to that of the homologous AprE176 [21] but different to the homologous fibrinolytic enzymes DC-4, NAT and BK-17, known to hydrolyse preferentially the polar residues lysine and arginine in the P1 position [39-41].

It should be noted that AprE127 was active under optimums of temperature, $\mathrm{pH}$ and $\mathrm{Mg}^{2+}$ concentration (1.2$1.4 \mathrm{mM}$ in blood plasma) close to physiologic conditions.

AprE127 acted directly by degrading insoluble fibrin fibers; thus, it should be assigned as a plasmin-like protease. The specificity of this molecule against fibrin was demonstrated by amidolytic assays of different synthetic substrates. These data suggest that AprE127 directly degraded fibrin. It is worth noting that direct-acting thrombolytic agents, like plasmin, have a striking hemostatic safety advantage over plasminogen activators in animal models of thrombolysis and bleeding. In contradistinction to plasminogen activators, which risk bleeding at any effective thrombolytic dose, plasmin is tolerated without bleeding at several-fold higher amounts than those needed for thrombolysis. Plasmin has been safe in a current trial in patients with peripheral arterial or graft occlusion, and efforts are now directed towards the therapy of strokes caused by cerebral artery occlusion [29].

Moreover, despite the AprE127's ability to quickly hydrolyse fibrin, it was also active in blood thrombus hydrolysis, as it was proved either by the reduction caused in fibrinolysis time of euglobulin or by the ability this enzyme had to dissolve thrombus in an in situ assay. Such observation suggested that this subtilisin is able to break down the rearrangements of fibrin in whole blood clots that are much more complex than in a simple fibrin plate agar. In blood clots, cross-linking bonds exist between the $\alpha$ chains and the $\gamma$ chains of fibrin, thus promoting a clot markedly more resistant to proteolytic and mechanical disruption [46].

Along with the fibrinolytic effect, AprE127 was also able to cause fibrinogen degradation, a pattern revealing that $\alpha, \beta$, and $\gamma$ chains were cleaved at different degrees until fibrinogen was hydrolysed. Such a pattern $(A \alpha>B \beta>$ $\gamma$ ) is similar to other fibrinolytic proteases [47-52]. Even though the pattern is similar, AprE127 completely degraded the three chains in comparatively less time than most of the subtilisins do. In contrast, AprE127 takes more time than the fibrinolytic metalloprotease purified from mycelia Perenniporia fraxinea [47] and than the fibrinolytic enzymes from Paenibacillus polymyxa EJS-3 [48], from Pleurotus eryngii [49] and the polychaete, Neanthes japonica [50]. However, the pattern of fibrinogen degradation by AprE127 is different from that of the fibrinolytic proteases of Streptomyces sp. CS684 and B. subtilis DC $33[53,54]$, which first hydrolyse $\beta$-chain.

In this fundamental work, it was proved that AprE127 was not toxic to cells in culture, and it is not hemolytic. Furthermore, this enzyme was able to cause a slight but evident reduction in the lengths of the infarcted region of a carrageenan-induced tail thrombosis test in rat in comparison with non-treated animals. This assay also 
suggested that the prophylactic effect of AprE127 injected at $0.4 \mathrm{mg} \cdot \mathrm{ml}^{-1}$ resembled that described for Nk, which was administered at higher doses, between 1 or $2 \mathrm{mg}^{-\mathrm{ml}^{-1}}$ [26]. Other studies, like Fujita et al. 1995 [28], have reported that nattokinase was four times more potent than plasmin in thrombus dissolution in rats, which is more potent than AprE127.

Despite that, contrary to AprE127, nattokinase not only degrades fibrin directly but also promotes the conversion of prourokinase to urokinase and increases t-PA formation [55], which is an indirect way of fibrin degradation by affecting plasminogen conversion to plasmin, and thus potentiates thrombolysis with less control of plasminogen activator levels in the blood, and, depending on the clinical case and the combination with other drugs, can lead to hemorrhagic complications [56].

In the case of AprE127, the mode of action is different, as it only acts directly by degrading insoluble fibrin fibers with activity similar to urokinase (Fig. 5A). Milner and Makise (2002) [57] have compared the fibrinolytic activity between nattokinase, urokinase and plasmin by the fibrin plate method, and nattokinase presented double the amount of fibrin lysis compared to the other two, while both urokinase and plasmin had the same fibrinolytic activity and thus supports the idea that AprE127, despite having lower thrombolytic activity than nattokinase, has the same fibrinolytic activity of plasmin, which is still considered a very potent thrombolytic agent.

In conclusion, our work demonstrates a new subtilisin, designated AprE127, that can be useful in overcoming important limitations of current agents, namely hemorrhagic complications. AprE127 was proved to be safe and to reduce thrombus extension in injected Wistar rats, with evident prevention of thrombus formation. Therefore, it has potential in the primary prevention of cardiovascular events. The uniqueness of AprE127 resides in a few differences in amino-acid sequences, which probably explain the differences observed in its substrate specificity and mode of action. More research should be done to completely elucidate the differences in AprE127 and to shed more light on the structure-function relationship.

\section{Acknowledgments}

This work was supported by Direção Regional da Ciência e Tecnologia - DRCT—Açores (Medida 2.2.2/I/025/ 2008). Duarte Toubarro received a post-doctoral grant (SFRH/BPD/77483/2011; M3.1.a/F/050/2016) from Fundação para a Ciência e Tecnologia, Portugal; Jorge Frias received a doctoral grant (SFRH/BD/131698/2017). The authors are grateful to Dr. Teresa Sampaio and Nélia Arruda, from Dr. Forjaz Sampaio Medical Center, for helping with the plasma anticoagulation assays. Duarte Toubarro and Nelson Simões designed the study and helped with the paper's redaction. Jorge Frias performed the experiments, analyzed the data and wrote the paper. Alexandra Fraga and Jorge Pedrosa performed thrombolytic assays in a rat model. Claudia Botelho and José Teixeira participated in the discussion and redaction of the paper.

\section{Conflict of Interest}

The authors have no financial conflicts of interest to declare.

\section{References}

1. WHO. 2016. Cardiovascular diseases (CVDs). Cardiovascular diseases (CVDs).

2. Raskob GE, Angchaisuksiri P, Blanco AN, Buller H, Gallus A, Hunt BJ, et al. 2014. Thrombosis: a major contributor to global disease burden. Arterioscler. Thromb. Vasc. Biol. 34: 2363-2371.

3. López-Sendón J, López de Sá E, Bobadilla JF, Rubio R, Bermejo J, Delcán JL. 1995. [Cardiovascular pharmacology (XIII). The efficacy of different thrombolytic drugs in the treatment of acute myocardial infarct]. Rev. Esp. Cardiol. 48: 407-439.

4. Mine Y, Kwan Wong AH, Jiang B. 2005. Fibrinolytic enzymes in Asian traditional fermented foods. Food Res. Int. 38: 243-250.

5. Duffy M. 2002. Urokinase plasminogen activator and its inhibitor, PAI-1, as prognostic markers in breast cancer: from pilot to level 1 evidence studies. Clin. Chem. 48: 1194-1197.

6. Collen D, Lijnen H. 2004. Tissue-type plasminogen activator: a historical perspective and personal account. J. Thromb. Haemost. 2: 541-546.

7. Kunamneni A, Abdelghani TT, Ellaiah P. 2007. Streptokinase--the drug of choice for thrombolytic therapy. J. Thromb. Thrombolysis 23: 9-23.

8. Murakami K, Yamanaka N, Ohnishi K, Fukayama M, Yoshino M. 2012. Inhibition of angiotensin I converting enzyme by subtilisin NAT (nattokinase) in natto, a Japanese traditional fermented food. Food Funct. 3: 674-678.

9. Medved L, Nieuwenhuizen W. 2003. Molecular mechanisms of initiation of fibrinolysis by fibrin. Thromb. Haemost. 89: 409-419.

10. Kumar A, Pulicherla KK, Ram KS, Rao KRSS. 2010. Evolutionary Trend of Thrombolytics. 2: 18 .

11. Cai D, Zhu C, Chen S. 2017. Microbial production of nattokinase: current progress, challenge and prospect. World J. Microbiol. Biotechnol. 33: 84

12. Kotb E. 2012. Fibrinolytic Bacterial Enzymes with Thrombolytic Activity, pp. 1-74. Fibrinolytic Bacterial Enzymes with Thrombolytic Activity, Ed. Springer Berlin Heidelberg,

13. Kotb E. 2013. Activity assessment of microbial fibrinolytic enzymes. Appl. Microbiol. Biotechnol. 97: 6647-6665.

14. Matseliukh OV, Nidialkova NA, Varbanets LD. 2012. [Purification and physicochemical properties of Bacillus thuringiensis IMB B7324 peptidase with elastolytic and fibrinolytic activity]. Ukr. Biokhim. Zh. (1999). 84: 25-36.

15. Nidialkova NA, Matseliukh OV, Varbanets LD. 2013. [Physico-chemical properties of Bacillus thuringiensis IMV B-7324 fibrinolytic peptidase]. Mikrobiol.Z. 75: 3-7.

16. Nidialkova NA, Matseliukh OV, Varbanets LD. 2012. [Isolation of Bacillus thuringiensis IMV B-7324 fibrinolytic peptidase]. Mikrobiol. Z. 74: 9-15.

17. Kumar DJM, Rakshitha R, Vidhya MA, Jennifer PS, Prasad S, Kumar MR, et al. 2014. Production, optimization and characterization of fibrinolytic enzyme by Bacillus subtilis RJAS19. Pak. J. Biol. Sci. 17: 529-534.

18. Anh DBQ, Mi NTT, Huy DNA, Hung PV. 2015. Isolation and optimization of growth condition of Bacillus sp. from fermented shrimp paste for high fibrinolytic enzyme production. Arab. J. Sci. Eng. 40: 23-28.

19. Lapsongphon N, Rodtong S, Yongsawatdigul J. 2013. Spent brewery yeast sludge as a single nitrogen source for fibrinolytic enzyme production of Virgibacillus sp. SK37. Food Sci. Biotechnol. 22: 71-78. 
20. Afifah DN, Sulchan M, Syah D, Yanti n, Suhartono MT, Kim JH. 2014. Purification and characterization of a fibrinolytic enzyme from Bacillus pumilus 2.g isolated from Gembus, an Indonesian fermented food. Prev. Nutr. Food Sci. 19: 213-219.

21. Jeong S-J, Heo K, Park JY, Lee KW, Park J-Y, Joo SH, et al. 2015. Characterization of AprE176, a fibrinolytic enzyme from Bacillus subtilis HK176. J. Microbiol. Biotechnol. 25: 89-97.

22. Vijayaraghavan P, Arun A, Vincent SGP, Arasu MV, Al-Dhabi NA. 2016. Cow dung is a novel feedstock for fibrinolytic enzyme production from newly isolated Bacillus sp. IND7 and its application in in vitro clot lysis. Front. Microbiol. 7:361.

23. Cho IH, Choi ES, Lim HG, Lee HH. 2004. Purification and characterization of six fibrinolytic serine-proteases from earthworm Lumbricus rubellus. J. Biochem. Mol. Biol. 37: 199-205.

24. Peng Y, Yang X, Zhang Y. 2005. Microbial fibrinolytic enzymes: an overview of source, production, properties, and thrombolytic activity in vivo. Appl. Microbiol. Biotechnol. 69: 126-132.

25. Choi NS, Chung DM, Ryu CR, Yoon KS, Maeng PJ, Kim SH. 2006. Identification of three extracelllar proteases from Bacillus subtilis KCTC 3014. J. Microbiol. Biotechnol. 16: 457-464.

26. Kamiya S, Hagimori M, Ogasawara M, Arakawa M. 2010. In vivo evaluation method of the effect of nattokinase on carrageenaninduced tail thrombosis in a rat model. Acta Haematol. 124: 218-224.

27. Xu J, Du M, Yang X, Chen Q, Chen H, Lin D-H. 2014. Thrombolytic effects in vivo of nattokinase in a carrageenan-induced rat model of thrombosis. Acta Haematol. 132: 247-253.

28. Fujita M, Hong K, Ito Y, Fujii R, Kariya K, Nishimuro S. 1995. Thrombolytic effect of nattokinase on a chemically induced thrombosis model in rat. Biol. Pharm. Bull. 18: 1387-1391.

29. Marder VJ, Jahan R, Gruber T, Goyal A, Arora V. 2010. Thrombolysis with plasmin: implications for stroke treatment. Stroke 41: S45-49.

30. Wang M, Yang W, Wu Q, Gu H. 2012. Modeling of the fibrin agarose plate assay and its application for thrombolytic analysis. Chin. Sci. Bull. 57: 3233-3238.

31. Salazar AM, Rodriguez-Acosta A, Girón ME, Aguilar I, Guerrero B. 2007. A comparative analysis of the clotting and fibrinolytic activities of the snake venom (Bothrops atrox) from different geographical areas in Venezuela. Thromb. Res. 120: 95-104.

32. Smith AA, Jacobson LJ, Miller BI, Hathaway WE, Manco-Johnson MJ. 2003. A new euglobulin clot lysis assay for global fibrinolysis. Thromb. Res. 112: 329-337.

33. Flemmig M, Melzig MF. 2012. Serine-proteases as plasminogen activators in terms of fibrinolysis. J. Pharm. Pharmacol. 64: 10251039.

34. Sumi H, Hamada H, Tsushima H, Mihara H, Muraki H. 1987. A novel fibrinolytic enzyme (nattokinase) in the vegetable cheese Natto; a typical and popular soybean food in the Japanese diet. Experientia 43: 1110-1111.

35. Peng Y, Yang X-J, Xiao L, Zhang Y-Z. 2004. Cloning and expression of a fibrinolytic enzyme (subtilisin DFE) gene from Bacillus amyloliquefaciens DC-4 in Bacillus subtilis. Res. Microbiol. 155: 167-173.

36. Fujita M, Nomura K, Hong K, Ito Y, Asada A, Nishimuro S. 1993. Purification and characterization of a strong fibrinolytic enzyme (nattokinase) in the vegetable cheese natto, a popular soybean fermented food in Japan. Biochem. Biophys. Res. Commun. 197: 13401347 .

37. Kim W, Choi K, Kim Y, Park H, Choi J, Lee Y, et al. 1996. Purification and characterization of a fibrinolytic enzyme produced from Bacillus sp. strain CK 11-4 screened from Chungkook-Jang. Appl. Environ. Microbiol. 62: 2482-2488.

38. Kim SH, Choi NS. 2000. Purification and characterization of subtilisin DJ-4 secreted by Bacillus sp. strain DJ-4 screened from DoenJang. Biosci. Biotechnol. Biochem. 64: 1722-1725.

39. Peng Y, Huang Q, Zhang RH, Zhang YZ. 2003. Purification and characterization of a fibrinolytic enzyme produced by Bacillus amyloliquefaciens DC-4 screened from douchi, a traditional Chinese soybean food. Comp. Biochem. Physiol. B Biochem. Mol. Biol. 134: $45-52$.

40. Jeong YK, Park JU, Baek H, Park SH, Kong IS, Kim DW, et al. 2001. Purification and biochemical characterization of a fibrinolytic enzyme from Bacillus subtilis BK-17. World J. Microbiol. Biotechnol. 17: 89-92.

41. Urano T, Ihara H, Umemura K, Suzuki Y, Oike M, Akita S, et al. 2001. The Profibrinolytic enzyme subtilisin NAT purified from Bacillus subtilis cleaves and inactivates plasminogen activator inhibitor type 1. J. Biol. Chem. 276: 24690-24696.

42. Kim H, Kim G, Kim D, Choi W, Park S, Jeong Y, et al. 1997. Purification and characterization of a novel fibrinolytic enzyme from Bacillus sp. KA38 originated from fermented fish. J. Ferment. Bioeng. 84: 307-312.

43. Lee SK, Bae DH, Kwon TJ, Lee SB, Lee HH, Park JH, et al. 2001. Purification and characterization of a fibrinolytic enzyme from Bacillus sp. KDO-13 isolated from soybean paste. J. Microbiol. Biotechnol. 11: 845-852.

44. Ko JH, Yan JP, Zhu L, Qi YP. 2004. Identification of two novel fibrinolytic enzymes from Bacillus subtilis QK02. Comp. Biochem. Physiol. C Toxicol. Pharmacol. 137: 65-74.

45. Choi NS, Yoo KH, Hahm JH, Yoon KS, Chang KT, Hyun BH, et al. 2005. Purification and characterization of a new peptidase, bacillopeptidase DJ-2, having fibrinolytic activity: produced by Bacillus sp. DJ-2 from Doen-Jang. J. Microbiol. Biotechnol. 15: 72-79.

46. Standeven KF, Carter AM, Grant PJ, Weisel JW, Chernysh I, Masova L, et al. 2007. Functional analysis of fibrin $\gamma$-chain cross-linking by activated factor XIII: determination of a cross-linking pattern that maximizes clot stiffness. Blood 110: 902-907.

47. Kim J-S, Kim J-E, Choi B-S, Park S-E, Sapkota K, Kim S, et al. 2008. Purification and characterization of fibrinolytic metalloprotease from Perenniporia fraxinea mycelia. Mycol. Res. 112: 990-998.

48. Lu F, Lu Z, Bie X, Yao Z, Wang Y, Lu Y, et al. 2010. Purification and characterization of a novel anticoagulant and fibrinolytic enzyme produced by endophytic bacterium Paenibacillus polymyxa EJS-3. Thromb. Res. 126: e349-355.

49. Cha W-S, Park S-S, Kim S-J, Choi D. 2010. Biochemical and enzymatic properties of a fibrinolytic enzyme from Pleurotus eryngii cultivated under solid-state conditions using corn cob. Bioresour. Technol. 101: 6475-6481.

50. Deng Z, Wang S, Li Q, Ji X, Zhang L, Hong M. 2010. Purification and characterization of a novel fibrinolytic enzyme from the polychaete, Neanthes japonica (Iznka). Bioresour. Technol. 101: 1954-1960.

51. Choi D, Cha W-S, Park N, Kim H-W, Lee JH, Park JS, et al. 2011. Purification and characterization of a novel fibrinolytic enzyme from fruiting bodies of Korean Cordyceps militaris. Bioresour. Technol. 102: 3279-3285.

52. Lee S-Y, Kim J-S, Kim J-E, Sapkota K, Shen M-H, Kim S, et al. 2005. Purification and characterization of fibrinolytic enzyme from cultured mycelia of Armillaria mellea. Protein Expr. Purif. 43: 10-17.

53. Wang CT, Ji BP, Li B, Nout R, Li PL, Ji H, et al. 2006. Purification and characterization of a fibrinolytic enzyme of Bacillus subtilis DC33, isolated from Chinese traditional Douchi. J. Ind. Microbiol. Biotechnol. 33: 750-758.

54. Simkhada JR, Mander P, Cho SS, Yoo JC. 2010. A novel fibrinolytic protease from Streptomyces sp. CS684. Process Biochem. 45: 88-93.

55. Chen H, McGowan EM, Ren N, Lal S, Nassif N, Shad-Kaneez F, et al. 2018. Nattokinase: A promising alternative in prevention and treatment of cardiovascular diseases. Biomark. Insights. 13: 1177271918785130.

56. Chang Y-Y, Liu J-S, Lai S-L, Wu H-S, Lan M-Y. 2008. Cerebellar hemorrhage provoked by combined use of nattokinase and aspirin in a patient with cerebral microbleeds. Intern. Med. 47: 467-469.

57. Milner M, Makise K. 2002. Natto and its active ingredient nattokinase: A potent and safe thrombolytic agent. Altern. Complement. Ther. 8: 157-164.

58. Nicklas W, Baneux P, Boot R, Decelle T, Deeny AA, Fumanelli M, et al. 2002. Recommendations for the health monitoring of rodent and rabbit colonies in breeding and experimental units. Lab. Anim. 36: 20-42. 